RELATOS Y RELACIONES DE H I PANOAMÉRICA COLONIA L 
THIS PAGE INTENTIONALLY LEFT BLANK 


\title{
RELATOS Y \\ RELACIONES DE \\ HISPANOAMÉRICA \\ COLONIAL
}

\author{
COMPILADO Y EDITADO POR \\ OTTO OLIVERA
}

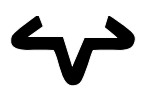

UNIVERSITY OF TEXAS PRESS

A U S TIN 
Copyright (C) 2004 by the University of Texas Press

All rights reserved

Printed in the United States of America

First edition, 2004

Requests for permission to reproduce material from this work should be sent to Permissions, University of Texas Press, Box 7819, Austin, TX 78713-7819.

(2) The paper used in this book meets the minimum requirements of ANSI/NISO Z39.48-I992 (RI997) (Permanence of Paper).

Library of Congress Cataloging-in-Publication Data

Relatos y relaciones de Hispanoamérica colonial / compilado y editado por Otto Olivera._- Ist. ed.

p. $\mathrm{cm}$.

Includes bibliographical references and index.

ISBN 0-292-7025 5-8-ISBN 0-292-70289-2 (pbk.)

I. Spanish American fiction-To I 800. 2. Spanish American

fiction-To I $800-$ History and criticism. I. Olivera, Otto.

$\mathrm{PQ70} 85 . \mathrm{R} 386 \quad 2004$

$863^{\prime} \cdot 30998-\mathrm{dc} 22$

2003065408 
Para Ruth

Por su constante ayuda 
THIS PAGE INTENTIONALLY LEFT BLANK 